\title{
Values for digestible indispensable amino acid scores (DIAAS) for some dairy and plant proteins may better describe protein quality than values calculated using the concept for protein digestibility-corrected amino acid scores (PDCAAS)
}

\author{
John K. Mathai ${ }^{1,2}$, Yanhong $\mathrm{Liu}^{2} \dagger$ and Hans H. Stein ${ }^{1,2 *}$ \\ ${ }^{1}$ Division of Nutritional Sciences, University of Illinois, Urbana, IL 61801, USA \\ ${ }^{2}$ Department of Animal Sciences, University of Illinois, Urbana, IL 61801, USA \\ (Submitted 7 June 2016 - Final revision received 14 December 2016 - Accepted 12 January 2017)
}

\section{Abstract}

An experiment was conducted to compare values for digestible indispensable amino acid scores (DIAAS) for four animal proteins and four plant proteins with values calculated as recommended for protein digestibility-corrected amino acid scores (PDCAAS), but determined in pigs instead of in rats. Values for standardised total tract digestibility (STTD) of crude protein (CP) and standardised ileal digestibility (SID) of amino acids (AA) were calculated for whey protein isolate (WPI), whey protein concentrate (WPC), milk protein concentrate (MPC), skimmed milk powder (SMP), pea protein concentrate (PPC), soya protein isolate (SPI), soya flour and whole-grain wheat. The PDCAAS-like values were calculated using the STTD of CP to estimate AA digestibility and values for DIAAS were calculated from values for SID of AA. Results indicated that values for SID of most indispensable AA in WPI, WPC and MPC were greater $(P<0.05)$ than for SMP, PPC, SPI, soya flour and wheat. With the exception of arginine and tryptophan, the SID of all indispensable AA in SPI was greater $(P<0.05)$ than in soya flour, and with the exception of threonine, the SID of all indispensable AA in wheat was less $(P<0 \cdot 05)$ than in all other ingredients. If the same scoring pattern for children between 6 and 36 months was used to calculate PDCAAS-like values and DIAAS, PDCAAS-like values were greater $(P<0 \cdot 05)$ than DIAAS values for SMP, PPC, SPI, soya flour and wheat indicating that PDCAAS-like values estimated in pigs may overestimate the quality of these proteins.

Key words: Amino acids: Dairy protein: Digestible indispensable amino acid scores: Protein digestibility-corrected amino acid scores: Plant protein

The protein digestibility-corrected amino acid score (PDCAAS) has been used for more than 20 years to evaluate protein quality in human foods ${ }^{(1)}$, but the PDCAAS procedure has limitations because values are calculated from the total tract digestibility of crude protein (CP) and calculations for PDCAAS are based on the assumption that all amino acids (AA) have the same digestibility as $\mathrm{CP}$. It is, however, recognised that digestibility of AA is most correctly determined at the end of the small intestine (the ileum), because AA are absorbed only from the small intestine and because hindgut fermentation can affect faecal AA excretion ${ }^{(2)}$. Therefore, ileal digestibility is a more accurate estimate of AA bioavailability than total tract digestibility in both humans and pigs ${ }^{(3,4)}$. In addition, the digestibility of $\mathrm{CP}$ is not representative of the digestibility of all $\mathrm{AA}^{(3)}$, because individual AA are digested with different efficiencies ${ }^{(3)}$. Other criticisms of the PDCAAS procedure have been recently reviewed and include use of truncation to avoid having values $>1$, use of a scoring pattern that is based on AA requirements for children and use of metabolic faecal $\mathrm{N}$ to correct for endogenous losses of $\mathrm{AA}^{(5-7)}$. It was also recently concluded that PDCAAS generally underestimates the value of high-quality proteins and overestimates the value of low-quality proteins ${ }^{(7)}$.

To avoid the flaws of the PDCAAS procedure, the Food and Agriculture Organization $(\mathrm{FAO})^{(8)}$ now recommends an AA evaluation procedure called digestible indispensable amino acid score (DIAAS). To calculate DIAAS, it is necessary to determine the digestibility of individual AA at the end of the small intestine (the ileum), and the pig has been recognised as an appropriate model for estimating $\mathrm{CP}$ and AA digestibility in foods for humans ${ }^{(8-10)}$. In contrast, PDCAAS values according to the original definition are determined in rats ${ }^{(1)}$. The apparent ileal digestibility of AA is defined as the net disappearance of ingested dietary AA from the digestive tract before the distal ileum ${ }^{(3)}$. If values for apparent ileal digestibility are corrected

\footnotetext{
Abbreviations: AA, amino acids; CP, crude protein; DIAAS, digestible indispensable amino acid score; MPC, milk protein concentrate; PDCAAS, protein digestibility-corrected amino acid score; PPC, pea protein concentrate; SID, standardised ileal digestibility; SMP, skimmed milk powder; SPI, soya protein isolate; STTD, standardised total tract digestibility; WPC, whey protein concentrate; WPI, whey protein isolate.
}

* Corresponding author: H. H. Stein, fax +1 217333 7088, email hstein@illinois.edu

$\dagger$ Present address: Department of Animal Science, University of California, Davis, CA 95616, USA. 
for the basal endogenous losses of AA, the resulting values are described as standardised ileal digestibility (SID) ${ }^{(3)}$. Values for SID of AA are additive in mixed diets ${ }^{(11)}$ and may be used to calculate DIAAS in proteins used in human nutrition ${ }^{(4,8)}$.

Research in our laboratory estimated DIAAS in eight cereal grains by calculating SID values for all indispensable AA in pigs $^{(4)}$. Results indicated that to meet dietary requirements for AA in humans, diets based on sorghum, wheat, rye or maize require more AA supplementation than diets based on polished rice or dehulled oats. However, in human nutrition, protein is usually supplied by either animal-based proteins or plant-based proteins. Animal proteins include a number of dairy products, and commonly used dairy proteins include whey protein concentrate (WPC), whey protein isolate (WPI), milk protein concentrate (MPC) and skimmed milk powder (SMP). Commonly used plant proteins include soya protein isolate (SPI), soya flour and pea protein concentrate (PPC). To our knowledge, there are no published values for DIAAS for these proteins that have been determined in pigs and it is not known how values for DIAAS determined in pigs compare with PDCAAS-like values determined in pigs. Therefore, the aim of this experiment was to compare PDCAAS-like values determined in pigs and values for DIAAS in eight commonly used proteins and test the hypothesis that values for DIAAS are more appropriate to quantify protein quality than values for PDCAAS.

\section{Methods}

The protocol for the experiment was reviewed and approved by the Institutional Animal Care and Use Committee at the University of Illinois (protocol no. 13354). Four dairy proteins (WPI, WPC, MPC and SMP) were procured from Cereal Byproducts Company. SPI and soya flour were obtained from Archer Daniels Midland Company and PPC was obtained from AGT Foods. Wheat was obtained from Siemers (Table 1). Each ingredient was included in one diet as the only source of $\mathrm{CP}$ and AA with the exception that wheat was included in combination with soya flour (Tables 2 and 3). A N-free diet was also formulated to measure basal endogenous losses of $\mathrm{CP}$ and AA. Vitamins and minerals were included in all diets to meet or exceed current requirement estimates for growing pigs ${ }^{(12)}$. All diets also contained $0.4 \%$ chromic oxide as an indigestible marker and all diets were provided in meal form.

Nine growing barrows (initial body weight: $26 \cdot 25$ (SD 1.48) kg) were equipped with a T-cannula in the distal ileum using procedures adapted from Stein et $a l .{ }^{(13)}$. Pigs were allowed a 7-d recovery after the surgery and they were then allotted to a $9 \times 9$ Latin square design with nine diets and nine 9-d periods. No pig received the same diet more than once during the experiment and there was, therefore, nine replicate pigs per treatment. With nine replicates we expected to be able to detect differences in SID values among ingredients of 2.5-4 percentage units (depending on the AA). Pigs were housed in individual pens $(0.9 \times 1.8 \mathrm{~m})$ in an environmentally controlled room. Pens had smooth sides and fully slatted concrete floors. A feeder and a nipple drinker were installed in each pen. At the conclusion of the experiment, pigs were approximately 19 weeks of age and had a body weight of 84.70 (sD 6.48$) \mathrm{kg}$.
All pigs were fed their assigned diets in a daily amount of three times the estimated energy requirement for maintenance (i. e. $824 \mathrm{~kJ}$ metabolisable energy $\left./ \mathrm{kg}^{0.60}\right)^{(12)}$. The daily feed allotment was provided every day at 08.00 hours. Water was available at all times. Pig weights were recorded at the beginning of each period and at the conclusion of the experiment. The amount of feed supplied each day was recorded as well. The initial $5 \mathrm{~d}$ of each period were considered an adaptation period to the diet. Faecal samples were collected on days 6 and 7 and immediately frozen at $-20^{\circ} \mathrm{C}$. Ileal digesta were collected for $8 \mathrm{~h}$ (from 08.00 to 16.00 hours) on days 8 and 9 using standard operating procedures ${ }^{(13)}$. In brief, cannulas were opened and cleaned, a plastic bag was attached to the cannula barrel and digesta flowing into the bag were collected. Bags were removed whenever they were filled with digesta or at least once every $30 \mathrm{~min}$, and immediately frozen at $-20^{\circ} \mathrm{C}$ to prevent bacterial degradation of the $\mathrm{AA}$ in the digesta. Individual pig weights recorded at the conclusion of each period were used to calculate the feed provision for the subsequent period.

At the conclusion of the experiment, faecal samples were dried in a forced air oven and finely ground through a 1-mm screen in a Wiley Mill (model 4; Thomas Scientific) before analysis. Ileal samples were thawed, mixed within animal and diet, and a sub-sample was collected for analysis. A sample of each source of protein and of each diet was collected at the time of diet mixing. Digesta samples were lyophilised and finely ground before chemical analysis. Diets, ingredients, faecal samples and ileal digesta samples were analysed for DM (method 927.05) (14) $^{2}$ and CP by combustion (method 990.03) (14) $^{(2)}$ on an Elementar Rapid N-cube protein/N apparatus (Elementar Americas Inc.). Aspartic acid was used as a calibration standard and $\mathrm{CP}$ was calculated as $\mathrm{N} \times 6 \cdot 25$. Samples were analysed in duplicate, but analyses were repeated if the analysed values were $>5 \%$ apart. Diets, faecal samples and ileal digesta were also analysed in duplicate for $\mathrm{Cr}$ (method 990.08) (14) $^{(1)}$ and all diets, ingredients and ileal digesta samples were analysed for AA on a Hitachi Amino Acid Analyzer (model L8800; Hitachi High Technologies America Inc.) using ninhydrin for postcolumn derivatisation and norleucine as the internal standard. Samples were hydrolysed with $6 \mathrm{~N}-\mathrm{HCl}$ for $24 \mathrm{~h}$ at $110^{\circ} \mathrm{C}$ before analysis, but methionine and cysteine were analysed as methionine sulfone and cysteic acid after cold performic acid oxidation overnight before hydrolysis and tryptophan was determined after $\mathrm{NaOH}$ hydrolysis for $22 \mathrm{~h}$ at $110^{\circ} \mathrm{C}$ (method $982 \cdot 30 \mathrm{E}(\mathrm{a}, \mathrm{b}, \mathrm{c}))^{(14)}$.

\section{Calculations}

Values for apparent ileal digestibility of $\mathrm{CP}$ and AA, basal endogenous losses of $\mathrm{CP}$ and $\mathrm{AA}$, and SID of CP and AA were calculated for all diets as previously explained ${ }^{(3)}$. For all ingredients except wheat, the SID for $\mathrm{CP}$ and $\mathrm{AA}$ in the diets also represented the SID of the ingredient, but for wheat, the SID of CP and AA were calculated using the difference procedure ${ }^{(15)}$. Values for the standardised total tract digestibility (STTD) of CP were calculated as explained for the calculation of SID of CP. 
Table 1. Analysed nutrient composition of ingredients (as-fed basis)*

\begin{tabular}{|c|c|c|c|c|c|c|c|c|}
\hline \multirow[b]{2}{*}{ Items } & \multicolumn{8}{|c|}{ Ingredients } \\
\hline & WPI & WPC & MPC & SMP & PPC & SPI & Soya flour & Wheat \\
\hline DM (\%) & 93.22 & 92.93 & 92.83 & 90.59 & 93.70 & 93.79 & $92 \cdot 23$ & 88.22 \\
\hline Crude protein (\%) & $85 \cdot 23$ & 78.01 & 67.93 & 34.65 & 54.46 & 92.66 & $52 \cdot 29$ & 11.67 \\
\hline $\mathrm{Ca}(\%)$ & 0.36 & 0.36 & $1 \cdot 77$ & 1.15 & 0.08 & 0.05 & 0.28 & 0.04 \\
\hline $\mathrm{P}(\%)$ & 0.23 & 0.31 & $1 \cdot 18$ & 0.91 & 0.69 & 0.73 & 0.69 & 0.37 \\
\hline \multicolumn{9}{|c|}{ Indispensable amino acids (\%) } \\
\hline Arg & 1.96 & $2 \cdot 38$ & 2.45 & 1.20 & 4.83 & 6.95 & 3.71 & 0.56 \\
\hline His & 1.71 & 1.72 & 2.04 & 1.07 & 1.43 & $2 \cdot 41$ & 1.43 & 0.30 \\
\hline Ile & 5.95 & 4.94 & $3 \cdot 61$ & 1.80 & $2 \cdot 31$ & 4.38 & $2 \cdot 35$ & 0.39 \\
\hline Leu & 9.91 & $9 \cdot 27$ & $6 \cdot 91$ & 3.47 & 4.04 & $7 \cdot 38$ & 4.00 & 0.78 \\
\hline Lys & 8.64 & 7.83 & $5 \cdot 50$ & 2.90 & $4 \cdot 11$ & 5.69 & $3 \cdot 30$ & 0.39 \\
\hline Met & 1.94 & 1.77 & 1.83 & 0.83 & 0.49 & $1 \cdot 18$ & 0.73 & 0.21 \\
\hline Phe & 2.85 & 2.87 & 3.42 & 1.70 & $2 \cdot 70$ & 4.86 & 2.60 & 0.52 \\
\hline Thr & 6.58 & $5 \cdot 39$ & 3.02 & 1.50 & 1.95 & 3.35 & 2.00 & 0.34 \\
\hline Trp & 1.83 & 1.57 & 1.01 & 0.54 & 0.48 & $1 \cdot 30$ & 0.79 & 0.12 \\
\hline Val & $5 \cdot 29$ & 4.83 & 4.43 & $2 \cdot 27$ & $2 \cdot 61$ & 4.42 & 2.53 & 0.52 \\
\hline \multicolumn{9}{|c|}{ Dispensable amino acids (\%) } \\
\hline Ala & 4.58 & $4 \cdot 20$ & $2 \cdot 27$ & $1 \cdot 14$ & $2 \cdot 25$ & 3.74 & $2 \cdot 20$ & 0.44 \\
\hline Asp & $10 \cdot 22$ & 8.79 & $5 \cdot 29$ & 2.68 & 5.99 & 10.56 & $5 \cdot 84$ & 0.62 \\
\hline Cys & $2 \cdot 14$ & 1.91 & 0.46 & 0.26 & 0.63 & 1.06 & 0.72 & 0.25 \\
\hline Glu & 15.97 & 13.62 & 14.55 & 7.37 & 8.62 & $17 \cdot 10$ & $9 \cdot 20$ & 3.06 \\
\hline Gly & 1.57 & 1.62 & 1.31 & 0.68 & 2.25 & 3.77 & $2 \cdot 16$ & 0.50 \\
\hline Pro & $5 \cdot 35$ & 4.50 & $6 \cdot 69$ & 3.33 & $2 \cdot 17$ & 4.65 & 2.52 & 1.03 \\
\hline Ser & $4 \cdot 10$ & 3.86 & 3.51 & 1.81 & $2 \cdot 37$ & 4.25 & $2 \cdot 33$ & 0.49 \\
\hline Tyr & 2.60 & 2.55 & 3.42 & 1.61 & 1.79 & 3.31 & $1 \cdot 82$ & 0.24 \\
\hline
\end{tabular}

WPI, whey protein isolate; WPC, whey protein concentrate; MPC, milk protein concentrate; SMP, skimmed milk powder; PPC, pea protein concentrate; SPI, soya protein isolate. * The trypsin inhibitor units in soya flour and SPI were 8.06 and 2.75 units $/ \mathrm{mg}$, respectively.

Table 2. Ingredient composition of experimental diets (as-is basis)*

\begin{tabular}{|c|c|c|c|c|c|c|c|c|c|}
\hline & \multicolumn{9}{|c|}{ Diets } \\
\hline & WPI & WPC & MPC & SMP & PPC & SPI & Soya flour & Wheat & $\mathrm{N}$-free \\
\hline \multicolumn{10}{|l|}{ Ingredients (\%) } \\
\hline WPI & 21.00 & - & - & - & - & - & - & - & - \\
\hline WPC & - & 23.00 & - & - & - & - & - & - & - \\
\hline MPC & - & - & $40 \cdot 00$ & - & - & - & - & - & - \\
\hline SMP & - & - & - & $50 \cdot 00$ & - & - & - & - & - \\
\hline PPC & - & - & - & - & $25 \cdot 00$ & - & - & - & - \\
\hline SPI & - & - & - & - & - & 21.00 & - & - & - \\
\hline Soya flour & - & - & - & - & - & - & 35.00 & $11 \cdot 30$ & - \\
\hline Wheat & - & - & - & - & - & - & - & 82.50 & - \\
\hline Soyabean oil & 3.00 & 3.00 & 3.00 & 3.00 & 3.00 & 3.00 & 3.00 & 3.00 & 4.00 \\
\hline Solka-Floc & - & - & - & - & - & - & - & - & 4.00 \\
\hline Monocalcium phosphate & 1.60 & 1.60 & 1.60 & 1.60 & 1.60 & 1.60 & 1.60 & 0.80 & $2 \cdot 40$ \\
\hline Limestone & 0.60 & 0.60 & 0.60 & 0.60 & $1 \cdot 30$ & $1 \cdot 30$ & 1.30 & $1 \cdot 30$ & 0.50 \\
\hline Sucrose & $20 \cdot 00$ & $20 \cdot 00$ & $20 \cdot 00$ & $20 \cdot 00$ & $20 \cdot 00$ & $20 \cdot 00$ & $20 \cdot 00$ & - & $20 \cdot 00$ \\
\hline Chromic oxide & 0.40 & 0.40 & 0.40 & 0.40 & 0.40 & 0.40 & 0.40 & 0.40 & 0.40 \\
\hline Maize starch & $52 \cdot 70$ & $50 \cdot 70$ & $33 \cdot 70$ & $23 \cdot 70$ & 48.00 & 52.00 & 38.00 & - & 67.50 \\
\hline Magnesium oxide & - & - & - & - & - & - & - & - & 0.10 \\
\hline Potassium carbonate & - & - & - & - & - & - & - & - & 0.40 \\
\hline Sodium chloride & 0.40 & 0.40 & 0.40 & 0.40 & 0.40 & 0.40 & 0.40 & 0.40 & 0.40 \\
\hline Vitamin-micromineral premix $†$ & 0.30 & 0.30 & 0.30 & 0.30 & 0.30 & 0.30 & 0.30 & 0.30 & 0.30 \\
\hline
\end{tabular}

WPI, whey protein isolate; WPC, whey protein concentrate; MPC, milk protein concentrate; SMP, skimmed milk powder; PPC, pea protein concentrate; SPI, soya protein isolate. * All diets were formulated to contain approximately $17 \%$ crude protein, $0.70 \%$ Ca and $0.33 \%$ standardised total tract digestible $P$.

† The vitamin-micromineral premix provided the following quantities of vitamins and micro minerals per $\mathrm{kg}$ of complete diet: vitamin $\mathrm{A}$ as retinyl acetate, $3.83 \mathrm{mg}$; vitamin $\mathrm{D}_{3}$ as cholecalciferol, $0.06 \mathrm{mg}$; vitamin $\mathrm{E}$ as DL- $\alpha$-tocopheryl acetate, $48.53 \mathrm{mg}$; vitamin $\mathrm{K}$ as menadione dimethylprimidinol bisulfite, $1.42 \mathrm{mg}$; thiamin as thiamine mononitrate, $0.24 \mathrm{mg}$; riboflavin, $6.59 \mathrm{mg}$; pyridoxine as pyridoxine hydrochloride, $0.24 \mathrm{mg}$; vitamin $\mathrm{B}_{12}, 0.03 \mathrm{mg}$; D-pantothenic acid as D-calcium pantothenate, $23.5 \mathrm{mg}$; niacin, $44.1 \mathrm{mg}$; folic acid, $1.59 \mathrm{mg}$; biotin, $0.44 \mathrm{mg}$; Cu, $20 \mathrm{mg}$ as copper sulfate and copper chloride; Fe, $126 \mathrm{mg}$ as ferrous sulfate; I, $1.26 \mathrm{mg}$ as ethylenediamine dihydriodide; Mn, $60.2 \mathrm{mg}$ as manganese sulfate; Se, $0.3 \mathrm{mg}$ as sodium selenite and Se yeast; and $\mathrm{Zn}, 125.1 \mathrm{mg}$ as zinc sulfate.

The concentration of SID AA $(\mathrm{g} / \mathrm{kg})$ in each ingredient was calculated by multiplying the SID value (\%) for each AA by the concentration $(\mathrm{g} / \mathrm{kg})$ of that $\mathrm{AA}$ in the ingredient, and this value was then divided by the concentration of $\mathrm{CP}$ in the ingredient to calculate digestible indispensable AA content $(\mathrm{mg})$ in $1 \mathrm{~g}$ protein $^{(4)}$. The digestible indispensable AA reference ratios 
Table 3. Analysed nutrient composition of experimental diets (as-fed basis)

\begin{tabular}{|c|c|c|c|c|c|c|c|c|c|}
\hline \multirow[b]{2}{*}{ Items } & \multicolumn{9}{|c|}{ Diets } \\
\hline & WPI & WPC & MPC & SMP & PPC & SPI & Soya flour & Wheat & $\mathrm{N}$-free \\
\hline DM (\%) & $93 \cdot 22$ & 92.93 & $92 \cdot 83$ & $90 \cdot 59$ & $93 \cdot 70$ & $93 \cdot 79$ & $92 \cdot 23$ & $88 \cdot 22$ & 92.41 \\
\hline Crude protein (\%) & $17 \cdot 61$ & $16 \cdot 35$ & $16 \cdot 90$ & $16 \cdot 76$ & $15 \cdot 65$ & $17 \cdot 04$ & $16 \cdot 53$ & $16 \cdot 59$ & 0.13 \\
\hline \multicolumn{10}{|c|}{ Indispensable amino acids (\%) } \\
\hline Arg & 0.39 & 0.49 & 0.58 & 0.55 & $1 \cdot 23$ & $1 \cdot 27$ & $1 \cdot 13$ & 1.00 & 0.01 \\
\hline His & 0.38 & 0.41 & 0.52 & 0.51 & 0.41 & 0.49 & 0.48 & 0.46 & 0.02 \\
\hline Ile & 1.27 & 1.08 & 0.91 & 0.88 & 0.64 & 0.86 & 0.77 & 0.69 & 0.01 \\
\hline Leu & 2.09 & 2.07 & 1.71 & 1.65 & $1 \cdot 10$ & 1.42 & 1.28 & 1.22 & 0.02 \\
\hline Lys & 1.85 & 1.72 & 1.37 & 1.38 & 1.13 & $1 \cdot 12$ & 1.05 & 0.80 & 0.02 \\
\hline Met & 0.40 & 0.39 & 0.46 & 0.42 & 0.13 & 0.23 & 0.22 & 0.26 & 0.00 \\
\hline Phe & 0.59 & 0.62 & 0.84 & 0.80 & 0.72 & 0.92 & 0.82 & 0.79 & 0.01 \\
\hline Thr & 1.39 & $1 \cdot 17$ & 0.73 & 0.70 & 0.52 & 0.64 & 0.63 & 0.56 & 0.01 \\
\hline Trp & 0.37 & 0.38 & 0.26 & 0.29 & 0.17 & 0.22 & 0.25 & 0.18 & 0.02 \\
\hline Val & $1 \cdot 15$ & 1.05 & $1 \cdot 13$ & 1.08 & 0.72 & 0.89 & 0.82 & 0.80 & 0.01 \\
\hline Total & 9.88 & $9 \cdot 38$ & 8.51 & $8 \cdot 26$ & $6 \cdot 77$ & 8.06 & $7 \cdot 45$ & $6 \cdot 76$ & 0.13 \\
\hline \multicolumn{10}{|c|}{ Dispensable amino acids (\%) } \\
\hline Ala & 0.99 & 0.95 & 0.57 & 0.55 & 0.62 & 0.73 & 0.71 & 0.68 & 0.01 \\
\hline Asp & $2 \cdot 17$ & 1.94 & $1 \cdot 30$ & $1 \cdot 27$ & 1.64 & $2 \cdot 02$ & 1.85 & $1 \cdot 37$ & 0.02 \\
\hline Cys & 0.43 & 0.42 & 0.11 & 0.12 & 0.16 & 0.20 & 0.22 & 0.31 & 0.00 \\
\hline Glu & 3.41 & 3.04 & 3.49 & 3.40 & $2 \cdot 38$ & $3 \cdot 29$ & 2.92 & 3.68 & 0.05 \\
\hline Gly & 0.34 & 0.37 & 0.31 & 0.32 & 0.62 & 0.72 & 0.69 & 0.70 & 0.01 \\
\hline Ser & $1 \cdot 10$ & 0.94 & 1.62 & 1.55 & 0.57 & 0.85 & 0.77 & $1 \cdot 12$ & 0.01 \\
\hline Tyr & 0.94 & 0.86 & 0.83 & 0.79 & 0.62 & 0.79 & $0 \cdot 70$ & 0.69 & 0.01 \\
\hline Ala & 0.46 & 0.48 & 0.74 & 0.70 & 0.43 & 0.54 & 0.54 & 0.51 & 0.01 \\
\hline Total & $9 \cdot 84$ & $9 \cdot 00$ & 8.97 & $8 \cdot 70$ & 7.04 & $9 \cdot 14$ & 8.40 & $9 \cdot 06$ & $0 \cdot 12$ \\
\hline Total amino acids (\%) & $19 \cdot 72$ & $18 \cdot 38$ & $17 \cdot 48$ & $16 \cdot 96$ & $13 \cdot 81$ & $17 \cdot 20$ & $15 \cdot 85$ & $15 \cdot 82$ & 0.25 \\
\hline
\end{tabular}

WPI, whey protein isolate; WPC, whey protein concentrate; MPC, milk protein concentrate; SMP, skimmed milk powder; PPC, pea protein concentrate; SPI, soya protein isolate.

were calculated for each ingredient using the following equation $^{(8)}$ : digestible indispensable AA reference ratio $=$ digestible indispensable AA content in $1 \mathrm{~g}$ protein of food $(\mathrm{mg}) / \mathrm{mg}$ of the same dietary indispensable AA in $1 \mathrm{~g}$ of the reference protein. The reference proteins were based on $\mathrm{FAO}^{(8)}$ and separate ratios were calculated using the reference protein for infants less than 6 months old, children from 6 to 36 months old and children older than 36 months, adolescents and adults ${ }^{(8)}$. The DIAAS values were then calculated using the following equation $^{(8)}$ :

DIAAS $(\%)=100 \times$ lowest value of the digestible indispensable

\section{AA reference ratio}

Values for STTD of CP were used to calculate PDCAAS-like values using the following equation ${ }^{(16)}$ :

PDCAAS-like values $(\%)=\mathrm{mg}$ of limiting AA in $1 \mathrm{~g}$ of

test protein/mg of the same AA in $1 \mathrm{~g}$ of reference protein

$\times$ standardised total tract digestibility $(\%) \times 100$.

Calculation of PDCAAS-like values used the reference protein for 2-5 year-old children as recommended if values are calculated from STTD of CP in rats ${ }^{(1)}$. However, to allow for a direct comparison between PDCAAS-like values and values for DIAAS, PDCAAS-like values were also calculated using the three reference proteins that were used to calculate DIAAS values ${ }^{(8)}$.

\section{Statistical analyses}

Normality of data was verified and outliers were identified using the UNIVARIATE and BOXPLOT procedures, respectively (SAS Inst. Inc.). Data were analysed by ANOVA using the MIXED procedure of SAS (SAS Institute Inc.) in a randomised complete block design with the pig as the experimental unit. The statistical model to determine differences in SID of AA values among ingredients included diet as the main effect and pig and period as random effects. The model to compare values for SID and STTD of CP within each ingredient included calculation procedure (SID or STTD) as main effect and pig and period as random effects. The model to compare values for DIAAS and PDCAAS used calculation procedure (DIAAS or PDCAAS) as main effect and pig and period as random effects. Treatment means were calculated using the LSMEANS statement, and if significant, means were separated using the PDIFF option of the MIXED procedure. Significance and tendency was considered at $P<0.05$ and $0.05 \leq P<0 \cdot 10$, respectively.

\section{Results}

All pigs remained healthy throughout the experiment and readily consumed their diets. Gross chemical composition of all ingredients was generally in agreement with published values ${ }^{(12)}$. The concentration of $\mathrm{CP}$ in ingredients ranged from 11.67 to $92 \cdot 66 \%$.

With the exception of tyrosine, the SID of all AA was not different between WPI and WPC (Table 4). The SID of isoleucine, cysteine and serine was less $(P<0.05)$ in MPC than 
Table 4. Standardised ileal digestibility of amino acids in ingredients ${ }^{\star}$ (Pooled standard errors)

\begin{tabular}{|c|c|c|c|c|c|c|c|c|c|c|}
\hline \multirow[b]{2}{*}{ Items } & \multicolumn{8}{|c|}{ Ingredients } & \multirow[b]{2}{*}{ Pooled SEM } & \multirow[b]{2}{*}{$P$} \\
\hline & WPI & WPC & MPC & SMP & PPC & SPI & Soya flour & Wheat & & \\
\hline \multicolumn{11}{|c|}{ Indispensable amino acids (\%) } \\
\hline Arg & $104^{\mathrm{a}}$ & $101^{a, b}$ & $102^{a, b}$ & $98^{\mathrm{d}}$ & $99^{c, d}$ & $101^{\mathrm{b}, \mathrm{c}}$ & $99^{c, d}$ & $87^{e}$ & 1.00 & $<0.05$ \\
\hline $\mathrm{His}$ & $100^{\mathrm{a}}$ & $97^{\mathrm{a}, \mathrm{b}}$ & $99^{\mathrm{a}}$ & $94^{\mathrm{b}, \mathrm{c}}$ & $95^{\mathrm{b}, \mathrm{c}}$ & $97^{\mathrm{a}, \mathrm{b}}$ & $92^{\mathrm{c}}$ & $85^{\mathrm{d}}$ & 1.55 & $<0.05$ \\
\hline Ile & $98^{\mathrm{a}}$ & $97^{\mathrm{a}, \mathrm{b}}$ & $93^{\mathrm{c}, \mathrm{d}}$ & $89^{\mathrm{e}}$ & $91^{\mathrm{d}}$ & $95^{\mathrm{b}, \mathrm{c}}$ & $92^{d}$ & $86^{f}$ & 1.00 & $<0.05$ \\
\hline Leu & $99^{\mathrm{a}}$ & $98^{\mathrm{a}}$ & $98^{\mathrm{a}}$ & $94^{\mathrm{b}}$ & $92^{c}$ & $95^{\mathrm{b}}$ & $91^{\mathrm{c}}$ & $86^{\mathrm{d}}$ & 0.74 & $<0.05$ \\
\hline Lys & $98^{\mathrm{a}}$ & $96^{a, b}$ & $96^{a, b}$ & $95^{\mathrm{a}, \mathrm{b}}$ & $96^{\mathrm{a}, \mathrm{b}}$ & $97^{\mathrm{a}}$ & $93^{b}$ & $77^{\mathrm{c}}$ & 1.31 & $<0.05$ \\
\hline Met & $98^{\mathrm{a}}$ & $97^{\mathrm{a}, \mathrm{b}}$ & $97^{\mathrm{a}, \mathrm{b}}$ & $96^{\mathrm{b}, \mathrm{c}}$ & $90^{e}$ & $96^{\mathrm{c}}$ & $93^{d}$ & $88^{f}$ & 0.58 & $<0.05$ \\
\hline Phe & $98^{\mathrm{a}}$ & $96^{a, b}$ & $97^{\mathrm{a}}$ & $94^{\mathrm{b}}$ & $92^{c}$ & $96^{a, b}$ & $92^{\mathrm{c}}$ & $87^{d}$ & 0.82 & $<0.05$ \\
\hline Thr & $94^{\mathrm{a}}$ & $91^{\mathrm{a}, \mathrm{b}, \mathrm{c}}$ & $93^{\mathrm{a}}$ & $82^{\mathrm{d}}$ & $88^{\mathrm{b}, \mathrm{c}}$ & $92^{a, b}$ & $87^{c}$ & $80^{d}$ & 1.91 & $<0.05$ \\
\hline $\operatorname{Trp}$ & $100^{\mathrm{a}}$ & $98^{\mathrm{a}, \mathrm{b}}$ & $97^{\mathrm{a}, \mathrm{b}}$ & $91^{\mathrm{d}}$ & $87^{e}$ & $96^{\mathrm{b}, \mathrm{c}}$ & $92^{c, d}$ & $74^{f}$ & 1.31 & $<0.05$ \\
\hline Val & $97^{\mathrm{a}}$ & $95^{\mathrm{a}, \mathrm{b}}$ & $94^{\mathrm{b}, \mathrm{c}}$ & $90^{d}$ & $89^{d}$ & $94^{\mathrm{b}}$ & $91^{c, d}$ & $83^{\mathrm{e}}$ & 1.22 & $<0.05$ \\
\hline Mean & $98^{\mathrm{a}}$ & $96^{\mathrm{a}}$ & $97^{\mathrm{a}}$ & $92^{b}$ & $93^{\mathrm{b}}$ & $96^{\mathrm{a}}$ & $93^{b}$ & $85^{c}$ & 0.90 & $<0.05$ \\
\hline \multicolumn{11}{|c|}{ Dispensable amino acids (\%) } \\
\hline Ala & $98^{\mathrm{a}}$ & $96^{a, b}$ & $96^{a, b}$ & $89^{d}$ & $92^{c, d}$ & $96^{\mathrm{a}, \mathrm{b}, \mathrm{c}}$ & $93^{\mathrm{b}, \mathrm{c}, \mathrm{d}}$ & $79^{e}$ & 1.51 & $<0.05$ \\
\hline Asp & $99^{\mathrm{a}}$ & $96^{\mathrm{a}, \mathrm{b}}$ & $97^{\mathrm{a}, \mathrm{b}}$ & $88^{\mathrm{c}}$ & $93^{\mathrm{b}}$ & $95^{\mathrm{a}, \mathrm{b}}$ & $88^{c}$ & $80^{a, b}$ & 1.63 & $<0.05$ \\
\hline Cys & $98^{\mathrm{a}}$ & $95^{\mathrm{a}, \mathrm{b}}$ & $85^{c, d}$ & $73^{e}$ & $75^{\mathrm{e}}$ & $91^{\mathrm{b}, \mathrm{c}}$ & $81^{d}$ & $86^{c, d}$ & 2.57 & $<0.05$ \\
\hline Glu & $98^{\mathrm{a}}$ & $96^{\mathrm{a}, \mathrm{b}, \mathrm{c}}$ & $94^{b, c, d}$ & $90^{\mathrm{e}}$ & $96^{a, b}$ & $97^{\mathrm{a}}$ & $92^{\mathrm{d}, \mathrm{e}}$ & $93^{c, d}$ & $1 \cdot 19$ & $<0.05$ \\
\hline Gly & $117^{\mathrm{a}}$ & $112^{\mathrm{a}}$ & $117^{\mathrm{a}}$ & $96^{\mathrm{b}}$ & $98^{\mathrm{b}}$ & $100^{\mathrm{b}}$ & $95^{\mathrm{b}}$ & $87^{c}$ & $3 \cdot 18$ & $<0.05$ \\
\hline Ser & $95^{\mathrm{a}, \mathrm{b}}$ & $92^{\mathrm{b}, \mathrm{c}}$ & $88^{d}$ & $80^{\mathrm{e}}$ & $91^{c, d}$ & $96^{\mathrm{a}}$ & $92^{\mathrm{b}, \mathrm{c}, \mathrm{d}}$ & $89^{c, d}$ & 1.90 & $<0.05$ \\
\hline Tyr & $99^{\mathrm{a}}$ & $96^{\mathrm{b}, \mathrm{c}}$ & $98^{\mathrm{a}, \mathrm{b}}$ & $95^{\mathrm{c}, \mathrm{d}}$ & $93^{d}$ & $96^{\mathrm{b}, \mathrm{c}}$ & $93^{d}$ & $90^{\mathrm{e}}$ & 0.97 & $<0.05$ \\
\hline Mean & $102^{\mathrm{a}}$ & $101^{a, b}$ & $99^{a, b, c}$ & $95^{\mathrm{d}}$ & $98^{\mathrm{b}, \mathrm{c}}$ & $101^{\mathrm{a}, \mathrm{b}}$ & $96^{c, d}$ & $94^{\mathrm{d}}$ & 1.38 & $<0.05$ \\
\hline Total amino acids & $100^{\mathrm{a}}$ & $98^{a}$ & $99^{a}$ & $94^{\mathrm{b}}$ & $96^{\mathrm{b}}$ & $99^{a}$ & $95^{\mathrm{b}}$ & $90^{c}$ & 1.07 & $<0.05$ \\
\hline
\end{tabular}

WPI, whey protein isolate; WPC, whey protein concentrate; MPC, milk protein concentrate; SMP, skimmed milk powder; PPC, pea protein concentrate; SPI, soya protein isolate. a,b,c,d,e,f Mean values within a row with unlike superscript letters are different $(P<0.05)$.

* Standardised ileal digestibility values were calculated by correcting values for apparent ileal digestibility for the basal ileal endogenous losses. Endogenous losses of amino acids were calculated from pigs fed the $\mathrm{N}$-free diet as follows ( $/ \mathrm{kg} \mathrm{DM}$ intake): arginine, 0.59; histidine, 0.20; isoleucine, 0.29; leucine, 0.49 ; lysine, $0.40 ;$ methionine, 0.08 ; phenylalanine, 0.29 ; threonine, 0.49 ; tryptophan, 0.10 ; valine, 0.40 ; alanine, 0.62 ; aspartic acid, 0.72 ; cysteine, $0.17 ;$ glutamic acid, $0.94 ;$ glycine, 1.50 ; serine, 0.43 ; tyrosine, 0.23 .

in WPI and WPC, and the SID of valine and glutamic acid was less $(P<0.05)$ in MPC than in WPI, but for all other AA, no differences among MPC, WPI and WPC were observed. However, the SID of most AA was greater $(P<0.05)$ in WPI, WPC and MPC than in SMP, PPC, soya flour and wheat, but for SPI, many AA had SID values that were not different from those in WPI, WPC and MPC. With the exception of arginine, tryptophan, alanine and glycine, the SID of all AA was greater $(P<0.05)$ in SPI than in soya flour. The SID of methionine, tryptophan and cysteine was less $(P<0.05)$ in PPC than in soya flour and the SID of aspartic acid and glutamic acid was greater $(P<0.05)$ in PPC than in soya flour, but for all other AA, no difference between these two ingredients was observed. The SID of all indispensable AA and of alanine and tyrosine was less $(P<0.05)$ in wheat than in all other ingredients.

The SID of CP was greater $(P<0 \cdot 05)$ than the STTD of CP for WPI, WPC and wheat (Table 5). In contrast, the STTD of CP was greater $(P<0.05)$ than the SID of CP in MPC, SMP and SPI, whereas no difference between SID and STTD of CP was observed for PPC and soya flour.

The protein digestibility-corrected AA reference ratios calculated according to the recommendations from $\mathrm{FAO} / \mathrm{WHO}^{(1)}$ but using pigs instead of rats and based on the scoring pattern for preschool children (2-5 years old) are presented in the online Supplementary Table SA. However, the protein digestibilitycorrected AA reference ratios calculated from STTD values of $\mathrm{CP}$ in pigs were also calculated according to $\mathrm{FAO}^{(8)}$ and based on requirements of infants (birth to 6 months of age), children
(6 months to 3 years of age) and older children (older than 3 years of age), adolescents and adults, and these values are presented in the online Supplementary Table SB. Likewise, the digestible indispensable $\mathrm{AA}$ reference ratios calculated according to $\mathrm{FAO}^{(8)}$ and based on the same three age groups are presented in the online Supplementary Table SC.

If PDCAAS-like values calculated according to $\mathrm{FAO} / \mathrm{WHO}^{(1)}$ were truncated as recommended, values for WPC, MPC, SMP were less $(P<0.05)$ than values for DIAAS, whereas PDCAASlike values for PPC, SPI, soya flour and wheat were greater $(P<0.05)$ than for DIAAS (Table 6$)$. However, if PDCAAS-like values were not truncated, the PDCAAS-like value for WPC was not different from DIAAS, but PDCAAS-like values for MPC and SMP were greater $(P<0.05)$ than DIAAS. If PDCAAS-like values were calculated according to the same scoring pattern as DIAAS $^{(8)}$, PDCAAS-like values for SMP, PPC, SPI, soya flour and wheat were greater $(P<0.05)$ than values for DIAAS, whereas the PDCAAS-like value for WPI was less $(P<0.05)$ than the DIAAS for WPI.

For values for DIAAS, the first-limiting AA in WPI and WPC was histidine, but for MPC, SMP, PPC, SPI and soya flour, the sulfur AA were first limiting, and lysine was first liming in wheat. If PDCAAS-like values were calculated using the same scoring patterns as used to calculate DIAAS, the first-limiting AA in the proteins was not different from those identified for DIAAS. However, if PDCAAS-like values were calculated using the original scoring patterns ${ }^{(1)}$, either truncated or not truncated, the first-limiting AA for whey proteins was the aromatic AA and threonine was first limiting in MPC and the sulfur AA were first 
Table 5. Standardised ileal digestibility (SID) and standardised total tract digestibility (STTD) of crude protein (CP) in ingredients

\begin{tabular}{lcccccccc}
\hline & \multicolumn{1}{c}{ Ingredients } \\
\cline { 2 - 8 } Items & WPI & WPC & MPC & SMP & PPC & SPI & Soya flour & Wheat \\
\hline SID of CP (\%) & 101 & 98 & 92 & 90 & 95 & 94 & 92 & 91 \\
STTD of CP (\%) & 96 & 97 & 97 & 96 & 94 & 96 & 90 & 3.1 \\
SEM & 2.7 & 0.9 & 3.5 & 3.6 & 1.8 & 0.6 & 4.5 \\
$P$ & 0.003 & 0.025 & 0.008 & 0.001 & 0.208 & $<0.001$ & 0.168 & 0.022 \\
\hline
\end{tabular}

WPI, whey protein isolate; WPC, whey protein concentrate; MPC, milk protein concentrate; SMP, skimmed milk powder; PPC, pea protein concentrate; SPI, soya protein isolate.

Table 6. Comparison of protein digestibility corrected amino acid scores (PDCAAS) and digestible indispensable amino acid scores (DIAAS) based on different requirement patterns* $\dagger$

\begin{tabular}{|c|c|c|c|c|c|c|}
\hline Ingredients & PDCAAS 1991‡ & PDCAAS 1991, untruncated & PDCAAS 2013§ & DIAAS & SEM & $P$ \\
\hline WPI & $99^{\mathrm{a}}(\mathrm{AAA})$ & $99^{\mathrm{b}}(\mathrm{AAA})$ & $97^{\mathrm{b}}$ (His) & $100^{a}$ (His) & 0.3 & $<0.0001$ \\
\hline WPC & $100^{\mathrm{b}}(\mathrm{AAA})$ & $107^{\mathrm{a}}(\mathrm{AAA})$ & $107^{\mathrm{a}}(\mathrm{His})$ & $107^{\mathrm{a}}(\mathrm{His})$ & 0.4 & $<0.0001$ \\
\hline MPC & $100^{c}(T h r)$ & $127^{\mathrm{a}}(\mathrm{Thr})$ & $121^{\mathrm{b}}(\mathrm{SAA})$ & $120^{\mathrm{b}}(\mathrm{SAA})$ & 0.5 & $<0.0001$ \\
\hline SMP & $100^{\mathrm{d}}(\mathrm{SAA})$ & $121^{a}(\mathrm{SAA})$ & $112^{\mathrm{b}}(\mathrm{SAA})$ & $105^{\mathrm{c}}(\mathrm{SAA})$ & 1.1 & $<0.0001$ \\
\hline PPC & $75^{\mathrm{a}}(\operatorname{Trp})$ & $75^{\mathrm{a}}(\operatorname{Trp})$ & $71^{\mathrm{b}}(\mathrm{SAA})$ & $62^{\mathrm{c}}$ (SAA) & 0.6 & $<0.0001$ \\
\hline SPI & $93^{a}(\mathrm{SAA})$ & $93^{a}(\mathrm{SAA})$ & $86^{\mathrm{b}}(\mathrm{SAA})$ & $84^{c}(\mathrm{SAA})$ & 0.5 & $<0.0001$ \\
\hline Soya flour & $98^{\mathrm{a}}$ (Lys) & $98^{a}$ (Lys) & $93^{b}(\mathrm{SAA})$ & $89^{c}(\mathrm{SAA})$ & 1.3 & $<0.0001$ \\
\hline Wheat & $50^{a}$ (Lys) & $50^{\mathrm{a}}$ (Lys) & $51^{\mathrm{a}}$ (Lys) & $45^{\mathrm{b}}$ (Lys) & 1.3 & 0.013 \\
\hline
\end{tabular}

WPI, whey protein isolate; AAA, aromatic amino acids (phenylalanine + tyrosine); WPC, whey protein concentrate; MPC, milk protein concentrate; SAA, sulfur amino acids (methionine + cysteine); SMP, skimmed milk powder; PPC, pea protein concentrate; SPI, soya protein isolate.

a,b,c,d Mean values within a row with unlike superscript letters are different $(P<0.05)$.

* Values for PDCAAS were calculated from the total tract digestibility of crude protein in pigs and values for DIAAS were calculated from the ileal digestibility of amino acids in pigs.

$\dagger$ First-limiting amino acid is in parenthesis.

¥ PDCAAS were calculated using the recommended amino acid scoring pattern for preschool children (2-5 years). The indispensable amino acids reference patterns are expressed as mg amino acid/g protein: histidine, 19; isoleucine, 28; leucine, 66; lysine, 58; sulfur amino acids, 25; aromatic amino acids, 63 ; threonine, 34 ; tryptophan, 11; valine, 35(1)

$\S$ PDCAAS and DIAAS were calculated using the recommended amino acid scoring pattern for a child ( 6 months to 3 years). The indispensable amino acid reference patterns are expressed as mg amino acid/g protein: histidine, 20; isoleucine, 32; leucine, 66; lysine, 57; sulfur amino acids, 27; aromatic amino acids, 52; threonine, 31; tryptophan, 8.5; valine, 40 (8).

Table 7. Comparison of protein digestibility-corrected amino acid scores (PDCAAS) and digestible indispensable amino acid scores (DIAAS) ${ }^{\star}$

\begin{tabular}{|c|c|c|c|c|c|c|c|c|}
\hline \multirow[b]{2}{*}{ Items } & \multicolumn{8}{|c|}{ Ingredients } \\
\hline & WPI & WPC & MPC & SMP & PPC & SPI & Soya flour & Wheat \\
\hline \multicolumn{9}{|c|}{ Birth to 6 months $\ddagger$} \\
\hline DIAAS & 67 (AAA) & 71 (AAA) & $85(\operatorname{Trp})$ & 81 (Thr) & 45 (Trp) & 68 (SAA) & 73 (Leu) & 37 (Lys) \\
\hline PDCAAS & 66 (AAA) & 72 (AAA) & 85 (Trp) & 88 (Trp) & 49 (Trp) & 71 (SAA) & 72 (Leu) & 42 (Lys) \\
\hline SEM & 0.30 & 0.48 & 0.51 & $2 \cdot 4$ & 0.42 & 0.68 & 0.83 & 1.2 \\
\hline$P$ & 0.062 & 0.164 & 0.743 & 0.039 & $<0.0001$ & 0.026 & 0.642 & 0.017 \\
\hline \multicolumn{9}{|c|}{3 years and above $\S$} \\
\hline DIAAS & 125 (His) & 133 (His) & 141 (SAA) & 123 (SAA) & 73 (SAA) & 98 (SAA) & 105 (SAA) & 54 (Lys) \\
\hline PDCAAS & 122 (His) & 134 (His) & $142(\mathrm{SAA})$ & 132 (SAA) & 84 (SAA) & 102 (SAA) & 109 (SAA) & 51 (Lys) \\
\hline SEM & 0.44 & 0.68 & 0.73 & 1.6 & 0.62 & 0.98 & 1.4 & 1.7 \\
\hline$P$ & $<0.001$ & 0.311 & 0.196 & 0.002 & $<0.0001$ & 0.028 & 0.053 & 0.220 \\
\hline
\end{tabular}

WPI, whey protein isolate; WPC, whey protein concentrate; MPC, milk protein concentrate; SMP, skimmed milk powder; PPC, pea protein concentrate; SPI, soya protein isolate; AAA, aromatic amino acids (phenylalanine + tyrosine); SAA, sulfur amino acids (methionine + cysteine).

* Values for PDCAAS were calculated from the total tract digestibility of crude protein in pigs and values for DIAAS were calculated from the ileal digestibility of amino acids in pigs.

† First-limiting amino acid is in parenthesis.

¥ PDCAAS and DIAAS were calculated using the recommended amino acid scoring pattern for an infant (birth-6 months). The indispensable amino acid reference patterns are expressed as mg amino acid/g protein: histidine, 21; isoleucine, 55; leucine, 96; lysine, 69; sulfur amino acids, 33; aromatic amino acids, 94; threonine, 44; tryptophan, 17; valine, $55^{(8)}$.

$\S$ PDCAAS and DIAAS were calculated using the recommended amino acid scoring pattern for children older than 3 years, adolescents and adults. The indispensable amino acid reference patterns are expressed as $\mathrm{mg}$ amino acid/g protein: histidine, 16; isoleucine, 30; leucine, 61; lysine, 48; sulfur amino acids, 23; aromatic amino acids, 41; threonine, 25; tryptophan, 6.6; valine, $40^{(8)}$.

limiting in SMP and SPI. However, the first-limiting AA in PPC was tryptophan, whereas lysine was first limiting in soya flour and wheat.

Calculated PDCAAS-like values for infants were greater $(P<0.05)$ than values for DIAAS for SMP, PPC, SPI and wheat, whereas the value for DIAAS for WPI tended $(P=0.062)$ to be greater than the PDCAAS-like value (Table 7 ). For children older than 3 years, adolescents and adults, PDCAAS-like values for SMP, PPC and SPI were greater $(P<0.05)$ than DIAAS, and the PDCAAS-like value for soya flour tended $(P=0.053)$ to be 
greater than DIAAS. In contrast, the DIAAS for WPI was greater $(P<0.05)$ than the PDCAAS-like value.

The first-limiting AA for DIAAS calculated for infants were the aromatic AA for the whey proteins, tryptophan for MPC and PPC, threonine for SMP, the sulfur AA for SPI, leucine for soya flour and lysine for wheat. The first-limiting AA for PDCAAS-like values calculated for infants in SMP was tryptophan, but for all other ingredients, the first-limiting $\mathrm{AA}$ in the calculation of DIAAS was also first limiting for PDCAAS-like values. For children $>3$ years old, adolescents and adults, the first-limiting AA for both DIAAS and PDCAAS-like values for all proteins were the same as those identified for children from 6 months to 3 years old.

\section{Discussion}

The amount and quality of protein consumed throughout the world varies depending on protein availability, AA composition of proteins and digestibility of $\mathrm{AA}^{(16)}$. In many parts of the world, plant proteins are the primary sources of AA in the $\operatorname{diet}^{(4,17,18)}$, whereas animal proteins are the primary sources of AA in other parts of the world ${ }^{(18)}$. However, the composition and digestibility of both of these types of proteins differ ${ }^{(4,19)}$, and both plant and animal proteins, therefore, need to be evaluated. In the present experiment we attempted to do that, but it is acknowledged that all proteins were fed as raw ingredients without the processing that these ingredients most often go through before consumption by humans. If processing changes the digestibility of the protein, results may be different. Other limitations of the experiment include the assumption that AA digestibility in growing castrated male pigs are representative of values obtained in both male and female humans of all ages.

In the current experiment, values for AA digestibility calculated from the total tract digestibility of $\mathrm{CP}$ were estimated from pigs although the rodent is the recommended model in the definition of PDCAAS ${ }^{(1)}$. However, it was the objective to determine if total tract digestibility values for $\mathrm{CP}$ can be used to accurately estimate ileal digestibility values of individual AA and if we had used a rodent to calculate PDCAAS values and the pig to calculate DIAAS values, any differences would have been confounded by using the two different animal models. It is, therefore, important that the comparison is done within the same animal and because the pig has been recommended as the preferred animal model to calculate DIAAS values ${ }^{(8)}$, we chose to use the pig to also calculate PDCAAS-like values in this study.

As expected, dairy proteins had greater SID values than the plant proteins and they are, therefore, considered high-quality proteins for humans ${ }^{(20-22)}$. Protein quality in WPC, SMP and SPI or soya protein concentrate have been studied in rats, and results indicated that WPC had greater PDCAAS than SMP, SPI and soya protein concentrate ${ }^{(7,19)}$. Results of this experiment agree with previous results and also indicate that the PDCAASlike value for WPC is greater than for SMP and that the whey proteins have a more balanced AA profile compared with whole milk protein. The major protein in SMP is casein, which has a low concentration of cysteine, and this may be the reason for the reduced PDCAAS-like value for SMP compared with WPC.
According to the FAO recommended AA patterns for older children, adolescents and adults and recommendations for nutrient claims, all dairy proteins tested in this experiment can be considered 'excellent/high' quality sources of protein, with DIAAS $\geq 100^{(8)}$. By the same guidelines, SPI and soya flour qualify as 'good' sources of protein, with a score $\geq 75$ and $<100$. In contrast, proteins with DIAAS $<75$ are recommended to make no claims regarding protein quality ${ }^{(8)}$, and PPC and wheat tested in this experiment fall into this category. However, it is recognised that the cut-off values for protein quality assessments that were proposed were arbitrarily chosen and not based on documented research ${ }^{(8)}$.

The N-free diet was used to estimate endogenous AA losses. Values obtained using this procedure are estimates for the basal endogenous losses that are independent of the diet and secreted only in response to DM being present in the small intestine ${ }^{(3)}$. In addition to the basal endogenous losses, diet-specific endogenous losses may also occur, but these losses will not be included in the values obtained from the $\mathrm{N}$-free diet, and therefore, diet-specific losses are debited against the ingredients in the calculations of SID values. Thus, if a specific diet or ingredient induces diet-specific endogenous losses because of high concentrations of dietary fibre or anti-nutritional factors, the SID values for that diet or ingredient will be reduced compared with values for a diet or ingredient that does not induce specific endogenous losses. However, because endogenous losses are really lost from the body, values for SID will give a better estimate of the AA that are available for metabolism than if values for diet-specific endogenous losses had not been debited against the ingredient or diet. The calculated values for the SID of glycine in several ingredients exceeded $100 \%$ in the current experiment, which is not biologically possible, but these values are an artifact that is caused by an overestimation of endogenous glycine, which often happens when the $\mathrm{N}$-free procedure is used to determine endogenous losses of $\mathrm{AA}^{(3)}$.

For all proteins, SID values were different among both indispensable and dispensable AA indicating that one single value cannot be used to estimate the digestibility of individual AA as is assumed in the calculation of PDCAAS ${ }^{(1)}$. For all ingredients used in this experiment with the exception of wheat, threonine had a lower SID value than lysine, which is usually the case for proteins that are not heat damaged. This is a result of the greater concentrations of threonine than of lysine and other indispensable $\mathrm{AA}$ in mucin protein secreted into the small intestine ${ }^{(23)}$. Mucin protein is resistant to protease digestion, and therefore is included in the endogenous protein fraction that reaches the distal end of the ileum in pigs without being hydrolysed. We are not aware of data for the AA composition of mucin in humans, but it has been reported that the ileal digestibility of threonine in humans is less than that of other indispensable AA, which indicates that mucin in humans also may have a high concentration of threonine ${ }^{(9,10)}$. The observation that both lysine and tryptophan in wheat had a lower SID value than threonine may indicate that the wheat used in this experiment had been heat damaged during drying or grinding.

The differences between values for SID and STTD of CP that were observed are in agreement with reports indicating that the 
apparent ileal digestibility of $\mathrm{CP}$ is different from the apparent total tract digestibility of $\mathrm{CP}^{(2,24)}$. In most cases, the total tract digestibility of $\mathrm{CP}$ is greater than the ileal digestibility because of absorption of ammonia from the hindgut ${ }^{(25,26)}$, but as illustrated in this experiment, in some cases, $\mathrm{N}$ may be secreted into the hindgut resulting in a reduced value for STTD compared with SID. However, because $\mathrm{N}$ exchange in the hindgut does not contribute to the AA balance in humans and monogastric animals and because AA are absorbed only in the small intestine, the differences between STTD and SID values illustrate why values for STTD do not always represent absorption of AA. Thus, the use of STTD of CP to estimate the digestibility of all AA in the PDCAAS system will result in inaccuracies of estimates for AA digestibility, which has also been previously illustrated ${ }^{(7,21)}$.

In addition to the lack of digestibility values for individual AA, a major limitation of the PDCAAS system is that all scores are truncated to $100 \%$ with the rationale that any amount of AA beyond the requirement pattern confers no additional benefit to the individual consuming the protein ${ }^{(8,16,26,27)}$. This assumption, however, neglects the complementary effect that excess AA may have in combination with AA from other proteins ${ }^{(26,27)}$, and as a consequence, PDCAAS values do not give credit for extra indispensable AA that a protein may add to a diet ${ }^{(26,28)}$. In contrast to the PDCAAS system, values for DIAAS are not truncated to $100 \%$, and therefore, give credit to a protein based on its value as a complementary source of AA with other sources of proteins in a mixed $\operatorname{diet}^{(7)}$.

Despite the challenges with the PDCAAS procedures, which have been previously reviewed ${ }^{(5,26,27)}$, it is important to recognise that criticism related to the scoring patterns that were originally suggested $^{(1)}$ can be easily overcome by adopting different scoring patterns. Indeed, in a later report from WHO/FAO, scoring patterns for several age groups of children, teenagers and adults were suggested ${ }^{(28)}$. Likewise, the problems associated with truncation can also be easily corrected by using untruncated values ${ }^{(26)}$. As a consequence, the principal methodological difference between values calculated for PDCAAS and values calculated for DIAAS is related to the assumption that the small intestinal absorption of individual AA can be predicted from the total tract digestibility of CP. As was clearly illustrated in this experiment, differences in the ileal digestibility among individual AA in all proteins exist with the digestibility of threonine being the least for most proteins. As a consequence, the ileal digestibility of AA cannot be accurately predicted from a single value obtained for the total tract digestibility of CP. It is also clearly illustrated that both STTD and SID of $\mathrm{CP}$ overestimate the ileal digestibility of AA for proteins with lower AA digestibility and as a consequence, values for PDCAAS that are predicted from the STTD of CP are expected to be less accurate for proteins with low AA digestibility than for proteins with greater AA digestibility. These principles are illustrated by the data in Table 6 where PDCAASlike values are calculated according to the original recommendation $^{(1)}$ with scoring patterns for 2-5-year-old children and all values are truncated to 100 . The observation that the PDCAASlike values for WPC, MPC and SMP are much less than values for DIAAS is a consequence of truncation. However, if values are not truncated, none of these proteins have PDCAAS-like values that are less than values for DIAAS. Indeed, removing the truncation resulted in PDCAAS-like values that were greater than values for DIAAS for six of the eight protein sources, indicating an overestimation of protein quality by using PDCAAS-like values. Values for DIAAS were calculated based on the scoring pattern for children from 6 to 36 months ${ }^{(8)}$, and because this scoring pattern is different from the original PDCAAS scoring pattern ${ }^{(1)}$, this will influence the calculations. However, even if the PDCAAS-like values were calculated using the DIAAS scoring pattern, PDCAAS-like values for five of the eight proteins were greater than values for DIAAS. This observation is a consequence of the fact that total tract digestibility of $\mathrm{CP}$ is usually greater than the ileal digestibility of AA as discussed above, and as expected, the difference between PDCAAS-like values and DIAAS is greater for proteins with lower AA digestibility than for proteins with greater digestibility. Thus, it appears that the major inaccuracies in the calculation of PDCAAS are a consequence of the incorrect assumption that the ileal digestibility of all indispensable AA can be predicted from the total tract digestibility of $\mathrm{CP}$. This inaccuracy will have greater impact on evaluation of proteins used in developing countries than in developed countries, because foods typically consumed in many developing countries have lower digestibility of $\mathrm{CP}$ than food typically consumed in developed countries $^{(29)}$.

If PDCAAS-like values and DIAAS values were calculated for children older than 6 months or for adults and if the same scoring pattern was used, no differences between the two methodologies in terms of predicting the first-limiting AA were observed with lysine being first limiting in wheat, histidine being first limiting in the whey proteins and the sulfur AA being first limiting in the whole milk proteins and the soya and pea proteins. However, if the original scoring pattern for PDCAAS was used, the predicted first-limiting AA were different for all proteins except SMP, PPC and wheat, which illustrates that the choice of scoring pattern will influence, which AA is predicted to be first limiting in a specific protein.

The observation that PDCAAS-like values and values for DIAAS were much less if the scoring pattern for infants (i. e. $<6$ months old) was used instead of scoring patterns for older children or adults illustrate the high-protein quality that is needed in proteins by infants. The fact that some of the proteins such as PPC and wheat, have very low DIAAS and PDCAAS-like values for infants is likely of minor consequence because these proteins are not expected to be used to a great extent in the feeding of infants.

In conclusion, data from this experiment indicate that PDCAAS-like values calculated from the total tract digestibility of CP in pigs and DIAAS values for dairy proteins are greater than for proteins obtained from soyabeans, peas or wheat. Data also indicate that for most proteins, significant differences between PDCAAS-like values and DIAAS were observed. Whereas some of the flaws in the calculation of PDCAAS can be corrected by using different scoring patterns, the fundamental problem with values for PDCAAS is that they are calculated using the incorrect assumption that the ileal digestibility of all AA can be predicted from the total tract digestibility of $\mathrm{CP}$. 
Because of this assumption, PDCAAS values do not accurately predict ileal AA digestibility and it appears that specifically for low-quality proteins, values for PDCAAS overestimate the protein quality. Thus, to better meet protein requirements of humans, specifically for individuals consuming diets that are low or marginal in digestible AA, values for DIAAS should be used to estimate protein quality of ingredients and diets.

\section{Acknowledgements}

Financial support for this experiment was provided by the National Dairy Institute, Rosemont, Illinois, USA (project no. DMI 2014-06352). The National Dairy Institute did not contribute to the design of the experiment, analysis of data or writing of this article.

The contributions of the authors were as follows: J. K. M. conducted the animal work and laboratory work, analysed the data and wrote the majority of the manuscript. Y. L. prepared the experiment proposal, secured approval from appropriate animal welfare regulatory bodies and contributed to calculations, data analysis and interpretation of data. H. H. S. was the principal investigator. He designed the experiment, oversaw the development of the experiment and wrote the final version of the manuscript.

The authors declare no conflicts of interest.

\section{Supplementary material}

For supplementary material/s referred to in this article, please visit https://doi.org/10.1017/S0007114517000125

\section{References}

1. Food and Agriculture Organization of the United Nations (1991) Report of a Joint FAO/WHO Expert Consultation. Protein quality evaluation. http://apps.who.int/iris/bitstream/ 1065/38133/1/9251030979_eng.pdf (accessed December 2015).

2. Sauer WC \& Ozimek L (1986) Digestibility of amino acids in swine: results and their practical applications. A review. Livest Prod Sci 15, 367-388.

3. Stein HH, Seve B, Fuller MF, et al. (2007) Invited review: amino acid bioavailability and digestibility in pig feed ingredients: terminology and application. I Anim SCi 85, 172-180.

4. Cervantes-Pahm SK, Liu Y \& Stein HH (2014) Digestible indispensable amino acid score and digestible amino acids in eight cereal grains. Br J Nutr 111, 1663-1672.

5. Schaafsma G (2012) Advantages and limitations of the protein digestibility-corrected amino acid score (PDCAAS) as a method for evaluating protein quality in human diets. $\mathrm{Br} J$ Nutr 108, S333-S336.

6. Gilani GS (2012) Background on international activities on protein quality assessment of foods. Br J Nutr 108, S168-S182.

7. Rutherfurd SM, Fanning AC, Miller BJ, et al. (2015) Protein digestibility-corrected amino acid scores and digestible indispensable amino acids scores differentially describe protein quality in growing male rats. J Nutr 145, 372-379.

8. Food and Agriculture Organization of the United Nations (2013) Report of an FAO Expert Consultation. Dietary protein quality evaluation in human nutrition. http://www.fao.org/ag/ humannutrition/35978-02317b979a686a57aa4593304ffc17f06.pdf (accessed December 2015)

9. Rowan AM, Moughan PJ, Wilson MN, et al. (1994) Comparison of the ileal and faecal digestibility of dietary amino acids in adult humans and evaluation of the pig as a model animal for digestion studies in man. Br J Nutr 71, 29-42.

10. Deglaire A, Bos C, Tomé D, et al. (2009) Ileal digestibility of dietary protein in the growing pig and adult human. Br J Nutr 102, 1752-1759.

11. Stein HH, Pedersen C, Wirt AR, et al. (2005) Additivity of values for apparent and standardized ileal digestibility of amino acids in mixed diets fed to growing pigs. J Anim Sci $\mathbf{8 3}$, $2387-2395$

12. National Research Council (2012) Nutrient Requirements of Swine, 11th rev. ed. Washington, DC: National Academies Press.

13. Stein HH, Shipley CF \& Easter RA (1998) Technical note: a technique for inserting a T-cannula into the distal ileum of pregnant sows. J Anim Sci 76, 1433-1436.

14. Association of Official Analytical Chemists (2007) Official Methods of Analysis of AOAC International, 18th ed. Gaithersburg, MD: AOAC.

15. Rojas OJ \& Stein HH (2013) Concentration of digestible and metabolizable energy and digestibility of amino acids in chicken meal, poultry byproduct meal, hydrolyzed porcine intestines, a spent hen-soybean meal mixture, and conventional soybean meal fed to weanling pigs. J Anim Sci 91 , 3220-3230

16. Schaafsma $G$ (2000) The protein digestibility-corrected amino acid score. J Nutr 130, 1865S-1867S.

17. Schonfeldt HC \& Hall NC (2012) Dietary protein quality and malnutrition in Africa. Br J Nutr 108, S69-S76.

18. Swaminathan S, Vaz M \& Kurpad AV (2012) Protein intakes in India. Br J Nutr 108, S50-S68.

19. Gilani GS \& Sepehr E (2003) Protein digestibility and quality in products containing antinutritional factors are adversely affected by old age in rats. $J$ Nutr 133, 220-225.

20. James LJ, Mattin L, Aldiss P, et al. (2014) Effect of whey protein isolate on rehydration after exercise. Amino Acids $\mathbf{4 6}$, $1217-1224$

21. McAllan L, Skuse P, Cotter PD, et al. (2014) Protein quality and the protein to carbohydrate ratio within a high fat diet influences energy balance and the gut microbiota in C57BL/ 6J mice. PLOS ONE 2, 1-13.

22. Stanstrup J, Schou SS, Holmer-Jensen J, et al. (2014) Whey protein delays gastric emptying and suppresses plasma fatty acids and their metabolites compared to casein, gluten and fish protein. J Proteome Res 13, 2396-2408.

23. Stein HH, Trottier NL, Bellaver C, et al. (1999) The effect of feeding level and physiological status on total flow and amino acid composition of endogenous protein at the distal ileum in swine. J Anim Sci 77, 1180-1187.

24. Knabe DA, LaRue DC, Gregg EJ, et al. (1989) Apparent digestibility of nitrogen and amino acids in protein feedstuffs by growing pigs. J Anim Sci 67, 441-458.

25. Hendriks WH, van Baal J \& Bosch G (2012) Ileal and faecal protein digestibility measurement in humans and other non-ruminants: a comparative species view. Br J Nutr 108, S247-S257.

26. Boye J, Wijesinha-Bettoni R \& Burlingame B (2012) Protein quality evaluation twenty years after the introduction of the protein digestibility corrected amino acid score method. $\mathrm{BrJ}$ Nutr 108, S183-S211.

27. Sarwar G (1997) The protein digestibility-corrected amino acid score method overestimates quality of proteins containing antinutritional factors and of poorly digestible proteins 
supplemented with limiting amino acids in rats. J Nutr $\mathbf{1 2 7}$, 758-764.

28. World Health Organization, Food and Agriculture Organization of the United Nations, United Nations University (2007) Report of a Joint WHO/FAO/UNU. Expert consultation protein and amino acid requirements in human nutrition.
http://apps.who.int/iris/bitstream/10665/43411/1/WHO_TRS 935_eng.pdf?ua=1/ (accessed April 2016).

29. Gilani GS, Cockell KA \& Sepehr E (2005) Effects of antinutritional factors on protein digestibility and amino acid availability in foods. $J A O A C$ Intl $\mathbf{8 8}, 967-987$. 